This is an open access article under the terms of the CC-BY 3.0 License.

Peer review method: Double-Blind

Date of acceptance: November 16, 2020

Date of publication: January 08,2021

Original scientific article

DOI: https://www.doi.org/10.47305/JLIA2163062to

\title{
VIETNAM AND INDIA'S APPROACH TO THE INDO-PACIFIC REGION: IMPLICATION FOR BILATERAL RELATION PROMOTION
}

\author{
Nguyen Thi Oanh \\ Institute for Indian and Southwest Asian Studies, \\ Vietnam Academy of Social Sciences - Hanoi, Vietnam \\ Faculty of International Studies, University of Social Sciences and \\ Humanities, Vietnam National University - Hanoi, Vietnam \\ ORCID iD: https://orcid.org/0000-0001-7750-423X \\ nguyenoanh1010@gmail.com \\ Pham Thuy Nguyen \\ Institute for Indian and Southwest Asian Studies, \\ Vietnam Academy of Social Sciences - Hanoi, Vietnam \\ ORCID iD: https://orcid.org/0000-0002-1157-5892 \\ nguyenpham198@gmail.com
}

\begin{abstract}
There have been tectonic shifts in the Indo-Pacific region, impacting relations among international actors, including traditionally close partners like Vietnam and India. By using the approach of realism and constructivism in international relations, this paper discusses Vietnam and India's approach to the Indo-Pacific region to expand their substantive strategic relationship. The paper finds out that geopolitical changes in the Indo-Pacific directly influence the bilateral relation and create challenges as well as opportunities. By using the SWOT model, the paper analyzes driving factors and challenges to the Vietnam-India relations. Through the findings, it suggests both countries need to take advantages of the regional cooperation to further Vietnam-India's strategic comprehensive partnership.
\end{abstract}

Keywords: Vietnam; India; Indo-Pacific; International Cooperation; SWOT Model 


\section{INTRODUCTION}

Vietnam and India's approach to the Indo-Pacific region involves increasing economic, geopolitical, and security connections between the Western Pacific and Indian Ocean regions as well as perspectives from Vietnam and India on regional and international issues. This approach has become increasingly vital not only for Vietnam and India to maintain their economic, security interest at global as well as regional and national level but also to cope with a rising China.

\section{LITERATURE REVIEW}

Both realism and constructivism concern the nongovernment factors of international relations. According to Thomas Hobbes, realism considers countries focus on their national interests, act for their gains. In the current regional situation, China has been acting to expand its influences and using aggressive methods in the East Sea (which China claimed the South China Sea) through strengthening marine modernization and military (Noguchi 2011). The emergence of China in the sea has brought regional countries to improve their marine activities and find a balance factor, leading to the forming of Indo-Pacific cooperation, with the involvement of the United States and India. In the context of forming the 'Indo-Pacific' area, involved countries like Vietnam, India, Australia, the US have their interest to engage in the cooperation, which is opportunities of economics and marine security.

Constructivism defines international relations based on shared ideas, rather than material forces, which fits the Vietnam-Indian relation in the context of Indo-Pacific. Under constructivism, countries' social identity is a factor influencing the country's decision of cooperation in the international environment. The national characteristics influence national interest and strategies (Behravesh 2011). From this point of view, countries with similar characteristics such as historical relations, regional interest like Vietnam and India have many advantages and driving force to develop their relationship. Based on international rules and norms, actors develop their relation, each actor or country has its own set of norms and rules in the international environment, which form their own identity that other actors can react accordingly. The emergence of the Indo-Pacific area is an ongoing process, encouraging regional countries, such as Vietnam, India, and Australia to look for a cooperative mechanism to engage regional maritime activities. This condition also becomes the bridge to push bilateral relations between Vietnam and India. The 'Indo-Pacific' stretches from the marine and mainland region between the Indian Ocean and the Pacific Ocean, the term- was mentioned by Prime Minister Shinzo Abe in his speech at the Indian Parliament (Ministry of Foreign Affairs of Japan 2007), and was used many times by the President of the United States, Mr. Donald Trump to replace the term 'Asia-Pacific'. 
Among Australian scholars, the term 'Indo-Pacific' appeared back in the 1950s (Tyler and Shearman 2013). As a country is located between the Indian Ocean and the Pacific, Australia has gradually increased its interest in Indo-Pacific, especially due to different factors, "India's rise, the increasing importance of Southeast Asia, a greater interest in energy flows, and the growing maritime presence of new external players" (Lion 2016, 9-23). Australia Defense White Paper (2016, 37-47) mentioned this region as a "stable wider region, which we now conceptualize as the emerging Indo-Pacific". The Australians view this reason as "connecting the Indian and Pacific Oceans through Southeast Asia" (Australia Defense White Paper 2016, 37-47), in which the focus is the Southeast Asian sea and important roles of ASEAN countries. In this region, multilateral cooperation between ASEAN and South Asian countries is also needed. From Australia's point of view, this term provides an economic and security opportunity for involved countries, including Australia, "The growing prosperity of the Indo-Pacific and the rulesbased global order on which Australia relies for open access to our trading partners are based on the maintenance of peace and stability" (Australia Defense White Paper 2016, 37-47) and it is influenced by the US-China relation.

With the new presidency of Mr. Donald Trump, the United States has promoted much tougher foreign policies, which aim to bring the nation to a leading position in the economy and ensure its security. The term 'Indo-Pacific' which is used to replace 'AsiaPacific' is considered to put India in its focus. Under the term, the Indo-US relation is to create marine cooperation to promote a trading corridor, strengthen bilateral relations. The United States intends to involve India in the QUAD group, consisting of the US, Japan, Australia, and India to deal with the rise of China. It can be said that the IndoPacific plays a crucial role in the foreign policy of the Trump administration and "critical for America's continued stability, security, and prosperity" (Dod 2018, 2-5). Hence, the US and India need to coordinate on different issues. The US intends to use this strategy to realize its 'American first' policy and India can become a balancing factor to rising China in the Indian and Pacific Ocean. In the Shangri La Dialogue in Singapore (June 2018), the Indo-Pacific appeared as the most interesting topic. In the speech of Singaporean PM, Mr. Lee Hsien Loong, he mentioned the role of ASEAN in Indo-Pacific, and the principles "ASEAN Centrality, openness, transparency, inclusivity, and a rulesbased approach, to enhance mutual trust, respect and benefit" (ASEAN 2018).

In recent years, there are changes in the Indo-Pacific Ocean region. The rise of China encourages various countries like India, Japan, and Australia to promote the idea of regional cooperation. Unilateral decisions by China to expand air zones, the militarization of the sea, and building new artificial islands create issues relating to the South China Sea. The Chinese presence in the Indian Ocean and the Gulf has attracted attention in many countries. There is increasing concern about the debt trap of China. In the Indian Ocean, China has been expanding its marine strategy includes seaports in countries where they got long-term leases. It is difficult to say if they are used for 
commercial purposes or other forms. Regional cooperation promotes security and creates economic opportunities and ensures countries' national interests. The statement from the Chinese government does not specifically demonstrate any response to the Indo-Pacific initiative, arguing that the Indian-Pacific regional cooperation should go according to the commitments made by the countries, is not aimed at a country. On the occasion of the opening of the first session of the 13th National Assembly on 08 March 2018, Mr. Wang Yi, Minister of Foreign Affairs of China, shows China's confidence in cooperation in the One Belt and One Road Initiative and not worried about the IndianPacific initiative. He said that this does not affect the relationship of both countries, the development orientation of the two countries is different, one side is the Dragon, the other is the Elephant, and both need cooperation instead of competition (Yi 2018). He implied that the two sides should support each other, such as India's need to support China in its Belt and Road Initiative.

India and some other countries share a similar viewpoint, that 'Indo-Pacific' is an open term, which means the Indo-Pacific region welcome cooperation among countries, and is not against any players. India also stays in Russia's 'Indo-Pacific' strategy as Russia is searching for stability in West Asia, a part of the Indo-Pacific geographical domain in India's viewpoint. However, according to Russian Foreign Minister Sergey Lavrov, in a meeting of the Dialogue of Young Diplomats from the Asia-Pacific Region on the sidelines of the Eastern Economic Forum (EEF), Vladivostok, 12 September 2018 (MID 2018), the challenge is that there has not been a clear principle system for India and other countries to cooperate in this region.

Most of the countries support the 'Indo-Pacific' concept and others require clearer definition and cooperation principles in this matter. All official statements regard the 'Indo-Pacific' region for economic and security cooperation. However, many scholars share the view that it is to challenge the rise of China. David Scott (2012) opines that this term shows the competition between the US and China, and the US engages India in its plans in the Indian Ocean (Scott 2012, 85-109). However, it is impossible to exclude China from the region, as its increasing marine appearance and operations.

Under the term 'Indo-Pacific', the initiative of the QUAD has been raised as a cooperation group of 4 countries including India, Japan, Australia, and the US. Many argue this is an old term in the changing environment. According to Kuni Miyake, President of the Foreign Policy Institute and Research Director at Canon Institute for Global Studies, the concept of 'Indo-Pacific' should be considered "Middle East-Asia" and it is hard for Japan to secure its interest in this area, "the concept may not be geographically sufficient to guarantee Japan's survival" (Mofa 2014, 1-5). Humphrey Hawksley, author of 'Asian Waters: The Struggle Over the South China Sea and the Strategy of Chinese Expansion', also shared the opinion that the Indo-Pacific initiative is an out of date idea with India as a weak link, in the context of China's rise in the last 20 years "while China has single-mindedly committed to military expansion, India has 
muddled along and, as with its overall development, has been left behind (Hawksley $2018,11)$. According to officials' statements and documents from the government and scholars of Vietnam and India, both countries support cooperation for the national interest based on strong existing relations. It is also the same views shared by other countries including Japan, Australia, and the United States.

Vietnamese scholars' views on Vietnam-India cooperation in the Indo-Pacific region are optimistic. Vietnam and India "share the strategic cooperation relationship, and have an important position of the two oceans: the Indian Ocean and the Pacific Ocean" (Thang 2018), hence, "Vietnam and India share pillars to sustain and uphold the aspiration of a "free and open Indo-Pacific region, which are essential for the realization of the goal of the Asian century" (Ganguly 2018, 18-31). Currently, although Vietnam and India have similar opportunities and challenges, both countries can overcome these challenges through bilateral cooperation for mutual benefits (Le 2018).

\section{METHODOLOGY}

The main methodology contains realism and constructivism approach to analyze the change in India, and Vietnam-Indian relations in the changing international context, from the view of the interaction between geostrategic and geopolitical interests among major countries. Indo-Vietnam relations have a long historical process - hence, the article also applies historical research methods. The frame of the paper uses the SWOT analysis model to find out the challenges strength and weakness of Vietnam-India bilateral relations in the Indo-Pacific region. The analysis and evaluation of the VietnamIndia relation in the Indo-Pacific context are based on official policies, national development strategies provided by the Ministry of External Affairs (MEA), official diplomatic statements, and the Vietnam government, Indian government, along with Western as well as Indian research materials.

\section{VIETNAM AND INDIA'S APPROACH TO THE INDO-PACIFIC REGION}

From Vietnam's point of view, cooperation is encouraged in terms of national security and defense, in the Indo-Pacific. Vietnam considered its geopolitical advantage through the East Sea, as a bridge connecting Southeast Asia with the rest of Asia, and on various marine time routes. President Tran Dai Quang mentioned the term 'IndoAsian-Pacific' in a speech on bilateral relations at the Nehru Memorial Museum and Library on 04 March 2018, to describe

a security and development space including the Indian Ocean, Asia, and the Pacific. He also suggested that the XXI century would be "the IndoAsian-Pacific Century', and regional countries must: (1) share a common vision of an open and rule-based area, and a common interest in 
maintaining peace, stability, and prosperity; (2) protect unrestricted maritime and commercial freedom and not allow the Indo-Asian-Pacific to be divided into areas of influence; (3) build a common space for coexistence and development in the belief that the Indo-Asian-Pacific is large enough for every nation to grow and prosper; and (4) establish effective mechanisms to maintain peace, stability, and rule of law, to ensure joint security, prevent conflict and war, and solve security challenges effectively (Le 2018, 1-7).

In the context of world politics undergoing tectonic changes, India is recognized as the nucleus of the Indo-Pacific regional security architecture along with the US, Japan, and Australia. From an Indian perspective, the 'Indo-Pacific' region refers to the maritime space stretching from the littorals of East Africa and West Asia, across the Indian Ocean and western Pacific Ocean, to the littorals of East Asia (Goshal 2018, 345). Prime Minister Narendra Modi described the Indian Ocean region as a compact that is "from of the shores Africa to that of the Americas" (MEA 2018).

India's approach to the Indo-Pacific region has a time-adjustment, consistent with national, regional, and global issues. This is reflected in the statement of some politicians, researchers, and official statements of India. In 1941, Indian politician, Kalidas Nag, used the term 'Indo-Pacific domain' to affirm India's longstanding civilization in the region. Dr. Gurpreet S. Khurana, Executive Director of the National Maritime Foundation in New Delhi, India and a Captain in the Indian Navy who is credited for being one of the first to use the term 'Indo-Pacific' in the context of strategic and geopolitical discourse in India describes at the "The Trans-Pacific View Insight Series and Explain the essence of "Indo-Pacific" as a geopolitical framework (Kuo 2018).

Jawaharlal Nehru, in his book 'The Discovery of India' (1945), observed that:

The Pacific is likely to take the place of the Atlantic in the future as a nerve center of the world. Though not directly a Pacific state, India will inevitably exercise an important influence there. India will also develop as the center of economic and political activity in the Indian Ocean area, in south-east Asia, and right up to the Middle East. Her position gives her economic and strategic importance, which is believed to develop rapidly in the future (IDSA 2018).

Most recently, India's approach to the Indo-Pacific region is evident in the documents elaborated further in the text. According to the Foreword of the 'Ensuring Secure Seas: Indian Maritime Security Strategy', the shift in worldview from a EuroAtlantic to an Indo-Pacific focus and "the repositioning of global economic and military power towards Asia has resulted in significant political, economic and social changes in the Indian Ocean Region and impacted India's maritime environment in tangible ways" 
(Defence 2017), region is considered the most important factor leading to a change in India's maritime strategic thinking in 2015.

In the 'India Japan Vision 2025 - Special Strategic and Global Partnership Working Together for Peace and Prosperity of the Indo-Pacific Region and the World' (2015), the 'Indo-Pacific' concept was mentioned 6 times. It affirmed "Recognizing that peace, stability, and development in the Indo-Pacific region is indispensable to their national security and prosperity, they reaffirmed that close cooperation between Japan and India is the key to achieve peace and stability in the region" and share the "Vision for Peace and Stability" in Indo -Pacific (MEA 2015).

In the 'India-Australia Joint Statement' during the State visit of Prime Minister of Australia to India between 9-12 April 2017,

two Prime Ministers reaffirmed their commitment to a peaceful and prosperous Indo-Pacific, based on mutual respect and cooperation" and "share a commitment to democratic values, rule of law, international peace and security, and shared prosperity. The strategic and economic interests of both countries are converging which opens up opportunities for working together in a rapidly changing region (MEA 2017).

In the 'United States and India Joint Statement: Prosperity through Partnership' (26 June 2017), as responsible powers in the Indo-Pacific region, President Trump and Prime Minister Modi agreed that

a close partnership between the United States and India is central to peace and stability in the region" and the leaders reiterated the importance of respecting freedom of navigation, overflight, and commerce throughout the region; call upon all nations to resolve territorial and maritime disputes peacefully and by international law; support bolstering regional economic connectivity through the transparent development of infrastructure and the use of responsible debt financing practices, while ensuring respect for sovereignty and territorial integrity, the rule of law, and the environment; and call on other nations in the region to adhere to these principles (Whitehouse 2017).

Also, Prime Minister Narendra Modi made a statement at the ASEAN Summit (Philippines 2017) affirming that "India's Act East Policy is shaped around the ASEAN, and its centrality in the regional security architecture of the Indo-Pacific region is evident" and "India assures the ASEAN of its steady support towards achieving a rulesbased regional security architecture that best attests to the region's interests and its peaceful development" (India 2017).

Further, the Indian Prime Minister at the Plenary Session of the India - ASEAN Commemorative Summit (25 January 2018), remarked that the ASEAN-India cooperation 
in maritime domains one of the key focus areas for growth and development of the Indo-Pacific region (Pib 2018). During the official visit of the Prime Minister of India to the Republic of Indonesia on 29-30 May 2018, the President of Indonesia, Mr. Joko Widodo, and Narendra Modi discussed the shared vision of the two countries on Maritime Cooperation in the Indo-Pacific and reiterated the importance of achieving a free, open, transparent, rules-based, peaceful, prosperous and inclusive Indo-Pacific region, where sovereignty and territorial integrity, international law, in particular UNCLOS, freedom of navigation and overflight, sustainable development and an open, free, fair and mutually beneficial trade and investment system are respected; Acknowledging the need to maintain maritime safety and security for peace, stability and sustainable economic growth and development in the Indo-Pacific marine region as enshrined in UNCLOS and relevant international laws (Pib2018).

The 'Indo-Pacific' region lies at the heart of India's foreign and security policy as stated by India's Prime Minister Narendra Modi in his keynote address at the IISS Shangri-La dialogue (01 June 2018). And this term was used more than ten times in his speech. He observed that

The Indo-Pacific is a natural region. It is also home to a vast array of global opportunities and challenges (...) the ten countries of South East Asia connect two great oceans in both geographical and civilizational sense. Inclusiveness, openness, and ASEAN centrality and unity, therefore, lie at the heart of the new Indo-Pacific. India does not see the Indo-Pacific Region as a strategy or as a club of limited members. Nor as a grouping that seeks to dominate. And by no means do we consider it as directed against any country. India's vision for the Indo-Pacific Region is, therefore, a positive one. And, it has many elements (MEA 2018).

In summary, India supports and promotes a rule-based order in the Indo-Pacific region.

\section{IMPLICATIONS FOR INDIA-VIETNAM RELATION PROMOTION}

Strength

Vietnam-India relations have been developing stably based on their longstanding relationship as President Ho Chi Minh once described as "a cloudless sky" (Thang 2017, 7-12). Nowadays, "the sky is not only blue but also shines" (Thang 2017, 712). This is the strong foundation for the development of a friendly relationship in an area with many complicated developments in the Indo-Pacific region. Currently, both India and Vietnam are increasingly asserting their position in the international market. 
While India is growing strongly, Vietnam is also rising to affirm its voice. This has contributed to strengthening the historical and civilization linkage, the common economic and strategic interests to create a new synergy in Vietnam - India relations.

According to former Indian Prime Minister Atal Bihari Vajpayee: "History and geography have set us (India and Vietnam) as strategic partners" (Thang 2017, 7-12). With India becoming the nucleus of the Indo-Pacific regional security architecture, India's position on geostrategic maps is increasingly being raised, at the same time, the cooperation between India and the subjects of this security structure will be strengthened, including Vietnam. President Tran Dai Quang and Prime Minister Modi in the Joint Statement signed during President Quang's visit to India "reiterated the importance of achieving a peaceful and prosperous Indo-Pacific region where sovereignty and international law, freedom of navigation and overflight, sustainable development and a free, fair and open trade and investment system are respected" (Pib 2018).

Besides, while India implements a multi-faced diplomacy strategy, Vietnam also pursues multilateral diplomacy, to promote a peaceful, cooperative, and joint development in the region. It proves that through passing difficulties and challenges together, Vietnam-India's bilateral relations are strengthened. Specifically, in the context of regional development, the connection in the Indo- Pacific region would bring mutual benefits to Vietnam and India, as the Indo-Pacific region is home to three of the world's largest economies (US, China, and Japan), 7 out of 8 fastest-growing economies and 7 out of 10 largest army forces in the world. This arterial and economically vibrant region will create driving factors for the growth of developing countries like Vietnam and India.

\section{Weakness}

Vietnam and India are geographical far from each other, with poor transport infrastructure connection, especially by sea. Besides, differences in culture, customs, and languages also affect the connection and the in-depth development in their bilateral relationship. In particular, Vietnam and India have differences in political institutions, national development strategies. While Vietnam pursues the one-party system with the Communist Party as the leading nucleus, India has a pluralist and opposition political system, in which political decisions, including foreign policíes, are often formed through the intricate, complex struggle of diverse parties and interest groups. Currently, the difference in international position between Vietnam and India also makes the two countries have flexible in balancing relations with other countries to ensure the stability of bilateral relations and the development of multilateral relations. Also, one of the other weaknesses in Vietnam-India relations is the Chinese factor. China's rise, and its coercive behavior and aggressive stance have created tensions among Southeast Asian countries. The current Indo-Pacific region attracts attention from both China and the US 
which can be seen through the Free and Open Indo-Pacific Strategy of the US and China's BRI initiative, which creates tensions and confrontation risk in the region, hence, promoting arms races among regional countries, threatens the Vietnam-India bilateral relations.

Opportunities

Cooperation opportunities between Vietnam and India in the current Indo Pacific regional context are shown in the following aspects:

Firstly, at the global system level, Vietnam-India relations in the context of the 'Indo-Pacific: Free and Open' has benefited from the following factors: an open global investment environment promoted by great powers, a global trend in peace and cooperation, the fourth industrial revolution. And having received greater attention from great and major countries such as the US, Japan, Australia, India, and ASEAN countries, the Indo-Pacific region will have stronger, dynamic economic development and will provide more opportunities for economic development, trade promotion, investment, and regional security which in turn create a new environment for development in the region. Moreover, with the 'Free and Open' Indo-Pacific Strategy, the US and QUAD will actively contribute to the maintenance of regional stability and prosperity as well as maritime security, promoting international cooperation.

Secondly, the prospect of cooperation between Vietnam and India in the IndoPacific region is based on the confluence of economic and strategic factors of the two countries in the region. Vietnam and India are two countries with a strategic partnership, which are two important players in two oceans: the Indian Ocean and the Pacific Ocean. While India plays a leading role in the Indian Ocean region, Vietnam occupies an important geographic position in the Pacific region, especially, Vietnam which has an important role in ASEAN. Today, despite the complex changes in the geopolitical landscape of the Indo-Pacific region, the convergence of strategic interests between India and Vietnam is a solid foundation for the cooperation of the two countries. Vietnam and India have numerous favorable conditions to become important partners, contributing to building a free and open area. Putting Vietnam-India relations in the strategic context of 'Indo-Pacific: Free and Open' is, therefore, a good prospect for both countries. Based on a comprehensive strategic partnership as well as similarity in assessing strategies, economic benefits, political values, and common security interests of both Vietnam and India, certainly, diplomatic, economic, and military relations will become deeper. Vietnam and India were elevated to a comprehensive strategic partnership in September 2016. Since then the bilateral and multilateral relations in all areas got deepened and became more practical. According to President Ram Nath Kovind: 
Vietnam and India share a vision for the Indo-Pacific region, of which the South China Sea is a critical component. We share a vision of a rules-based order that respects the sovereignty and territorial integrity, ensures freedom of navigation and over-flight, as well as unimpeded commerce (...) We are both ancient maritime nations and are stake-holders in the commerce, security, and stability of the Indo-Pacific region. Above all, we share the same values (Indianexpress 2018).

Thirdly, India, and Vietnam have much in common. Both are gradually shifting from balanced power in the regional and global context to become important actors in international relations. Both have adjusted 'multilateral' foreign policy in international relations. With new realities - geopolitics and geo-economy, Vietnam is even more in line with India's plan in all aspects than ever before, especially in India's Act East Policy. In particular, security and defense cooperation continues to be an important pillar of India-Vietnam relations. At a time when the Chinese and the US trade confrontation is heating up, India and Vietnam can create mechanisms and tools to bring trade and investment to new heights. The mission of the two governments is to make Indian Vietnamese relations transform. Even though the 'Indo' in 'Indo-Pacific' represents the Indian Ocean and not India, the global community expects India to play a major role in terms of ensuring a maritime environment that is conducive for economic growth and development (Kuo 2018). India also sees ASEAN as a fundamental element for the structure of the Asian economic community to bring about peace and prosperity in the region. With the central position in the ASEAN region, Vietnam is an important partner in the relationship between India and ASEAN. The new context in the Indian Ocean and the Pacific Ocean contributes to the two countries' efforts to cooperate, not only in trade but also has great potential in the areas of economic defense, science, and technology, infrastructure development.

Fourthly, in the context of the US deploying the 'Indo-Pacific: Free and Open' Strategy, equal and free competition will be created, completely independent of the Chinese Belt and Road Initiative. On the other hand, this strategy creates more motivation and resources to strengthen the defense and security potential of countries in the region including Vietnam and India. The two countries have the opportunity to take advantage of factors such as technology, capital, contributing to socio-economic development, strengthening national defense and security, dealing with traditional and non-communication security challenges. At the same time, there is also a favorable condition for Vietnam-India to promote trade and investment exchanges and promote defense and security cooperation with each other and with other partners in the region. Also, the adjustment of the US's 'Indo-Pacific: Free and Open' Strategy raises strong competition in relations between major powers, creating opportunities for VietnamIndia as well as countries in the region to take the advantage of cooperation to build 
and enhance scientific and technological potentials, serving the modernization of their army.

Fifthly, in the 'Indo-Pacific: Free and Open' context, India is an important factor, directly involved in securing security in the open Western Pacific region. India will become an active partner within the framework of the 'Indo-Pacific: Free and Open'. Thus, Vietnam has favorable conditions to promote relations with India in the field of defense and security. On the contrary, as an important subject in ASEAN, Vietnam has made an important contribution to the implementation of India's Act East Policy. This platform contributes to promoting bilateral relations at bilateral as well as multilateral levels. Besides, Vietnam has always maintained its foreign policy of independence, selfreliance, multilateralism, and diversification of international, which attaches great importance to enhancing traditional friendship and multi-faceted cooperation with India.

Finally, Vietnam and India can play a leading role in the Indo-Pacific Ocean by strengthening bilateral relations and strengthening coordination in regional and subregional multilateral initiatives such as 1) APEC: because Vietnam not only is a close partner to India in the Indo-Pacific but also one of the important components in APEC, so it has great potential to play a facilitating role for India officially became a full member of APEC. Vietnam itself has repeatedly mentioned support for India becoming a permanent member of the United Nations Security Council and joining APEC; 2) EAS: Vietnam and India are important partners and support regional cooperation on priority areas identified in the EAS framework such as energy, finance, education, health, epidemics, and ASEAN connectivity. And in the future, it is possible to expand into maritime cooperation. Based on this foundation, the two countries will become important partners to peacefully resolve maritime disputes under international law and expand cooperation on infrastructure and bilateral connections; 3) RCEP: This institution is led by ASEAN including Japan, Korea, China, India, Australia, and New Zealand - this is an important mechanism in the current system of multilateral mines. As a trade agreement covering the areas of goods, services, investment, economic and economic cooperation, competition, and intellectual property, RCEP is expected to bring free trade agreements goods to the countries in this institution, including both Vietnam and India. This is an opportunity for Vietnam and Asia to participate in the supply chain of the world economy currently operating effectively in Southeast Asia. As members of RCEP, both countries can play an important role in promoting negotiations to establish a successful regional economic integration model in the Indo-Pacific. 
However, despite several advantages, the 'Indo - Pacific: Free and Open' context has also created many geopolitical changes which are challenges for Vietnam - India relations.

First, in terms of security, in the Indo-Pacific region, there are existing strategies of major countries at the same time, the 'US-Indo-Pacific: Free and Open' Strategy and China's Belt and Road Initiative. Thus, the confrontation between these initiatives threatens to push the region into intense competition, especially in the South China Sea and the East China Sea. In particular, the trade war between the US and China also partly affects India and Vietnam relations. This context also makes countries in the region continue to increase arms race and the situation is more complicated. Thus, this is likely to make Vietnam-India head into that common spiral. Currently, territorial disputes in the South China Sea have not been resolved. While both Vietnam and India support a law-based order, China has its claims in the sea. This will make it very difficult for countries to maintain the 'free and open' area.

Second, there is a gap between Vietnam and India within the Indo-Pacific geography which leads to differences in strategic priorities. Besides, the two countries differ in their perception of the nature of the threat China poses in the Indo-Pacific region.

Third, obstacles to the development of Vietnam-India relations from the cultural, religious, political-institutional factors as well as lack of mutual understanding and limited information about each other's market.

Fourth, the impact of competition among major power in the Indo-Pacific region. This region is fast changing with many intertwined trends, such as competition for influence as well as increased interdependence among countries (great countries as well as middle and small countries), that poses a question for Vietnam-India cooperation.

\section{CONCLUSION}

Vietnam and India have a long-standing relationship with similarities in terms of culture. Also, there is a common interest in cooperation and development. Therefore, strengthening and improving the effectiveness of Vietnam-India cooperation becomes crucial for each country, as this will fall in line with the new developmental trend of the Indo-Pacific region. In the future, it is hoped that the Indo-Pacific region will grow dynamically and become a driving force for the development of the world economy. With the new approach, India - a large country, pursuing rules and order, will be a positive force and factor for stable, peaceful, and prosperous development in the region. Research results indicate that in this context, when the 'Indo-Pacific: Free and Open' Strategy gets deployed, Vietnam and India with its geostrategic advantage - having 
important resources for development, and new opportunities, must jointly identify and articulate the Indo-Pacific's vision effectively to turn the XXI century into an Asian century, thereby, strengthening the India-Vietnam relations to further contribute to peace, stability, and security in the region.

The strengths, weaknesses, opportunities, and threats we analyzed above are sketches for the overall picture of Vietnam-India relations now and in the future of the Indo-Pacific region. Potential and barriers, opportunities, and threats are related to each other. If promoting strengths and potentials, will reduce barriers, overcome weaknesses and threats. On the contrary, removing a barrier will contribute to the full potential and reduce other threats. To do that, it is necessary for the great consensus and determination of the two countries. At the macro level, Vietnam and India already have strong relationships, loyalty, and high political beliefs. At the strategic level, the two countries need to promote the intelligence and dynamism of the two communities, including important scholars, intellectuals, leaders, line ministries, branches, and localities. Believing that Vietnam-India relations in the context of the Indo-Pacific region will increasingly develop, enrich and strengthen the strategic partnership between the two countries for the national interest, for peace, stability, and development of the region and the world. 


\section{REFERENCES}

1. Asian. 2018. "Chairman's statement of the 13th East Asia Summit Singapore". Last modified November 15.

https://asean.org/storage/2018/11/East Asia Summit Chairman Statement Final. pdf

2. Behravesh, Maysam. 2011. Constructivism: An Introduction. E-International Relations. ISSN 2053-8626.

3. Defence. 2017. "Australia Defense White Paper". Accessed August 20. http://www.defence.gov.au/WhitePaper/Docs/2016-Defence-White-Paper.pdf

4. Dod. 2018. "Remarks by Secretary Mattis at Plenary Session of the 2018 ShangriLa Dialogue". Accessed May 19.

https://dod.defense.gov/News/Transcripts/TranscriptView/Article/1538599/remarks-by-secretary-mattis-at-plenary-session-of-the2018-shangri-la-dialogue

5. Fpwhitepaper. 2018. "Australia Defense White Paper". Accessed October 19. https://www.fpwhitepaper.gov.au/foreign-policy-white-paper/chapter-threestable-and-prosperous-indo-pa-cific/indo-pacific

6. Goshal, Baladas. 2018. "Strategic geopolitical of Indo - Pacific: free and open strategy", International Scientific Conference Proceeding VietNam - India Development cooperation in economy, defense, security in the context of free and open Indo - Pacific region. National Political Publishing House. p. 346

7. Hawksley, Humphrey. 2018. Asian Waters: The Struggle Over the South China Sea and the Strategy of Chinese Expansion. The Overlook Press.

8. IDSA. 2018. "Abhay Kumar Singh replied Sampath Kumar question on" How does India benefit by engaging with littoral states in the Indo-Pacific?" Accessed December 20. https://idsa.in/askanexpert/india-engaging-with-littoral-states-inthe-indo-pacific

9. India. 2017. "Full Statement of Prime Minister Narendra Modi at 15th ASEANIndia Summit". Manila. Last modified November 14. https://www.india.com/news/india/opening-statement-by-prime-minister-at15th-asean-india-summit-manila-2633190/

10. Indian navy. 2015. Ensuring Secure Seas: Indian Maritime Security Strategy, Naval Strategic Publication (NSP). Last modified 12 October. Indian Navy. Accessed December 20. https://www.indiannavy.nic.in/sites/default/files/Indian Maritime Security Strateg y Document 25Jan16.pdf

11. Indianexpress. 2018. "India, Vietnam share vision of rules-based order in IndoPacific: Kovind". Accessed July 20. https://indianexpress.com/article/india/india- 
vietnam-share-vision-of-rules-based-order-in-indo-pacific-says-presidentkovind-5455616/

12. Kuo, Marcy. 2018."The Origin of 'Indo-Pacific' as Geopolitical Construct Image Credit: U.S. Pacific Command/Flickr The Origin of 'Indo-Pacific' as Geopolitical Construct". Last modified January 25. https://thediplomat.com/2018/01/theorigin-of-indo-pacific-as-geopolitical-construct/

13. Le, Hong Hiep. 2018."The U.S. Free and Open Indo-Pacific: A view from Vietnam". Accessed December 18. http://nghiencuuquocte.org/2018/08/20/an-do-duongthai-binh-duong-viet-nam/

14. Lion, Roy. 2016. "The Indo-Pacific and the nature of conjoinment". Accessed July 18. https://www.aspistrategist.org.au/indo-pacific-nature-conjoinment/

15. MEA. 2015. "Joint Statement on India and Japan Vision 2025". Last modified December 12. https://www.mea.gov.in/bilateraldocuments.htm?dtt/26176/

16. MEA. 2017. "India Australia Joint Statement during the State Visit of Prime Minister of Australia to India". Last modified April 10. https://www.mea.gov.in/bilateraldocuments.htm?dtl/28367/IndiaAustralia+Joint+ Statement+during +the+State+visit+of+Prime+Minister+of+Australia+to+India

17. MEA. 2018. "PM's Keynote Address at Shangri La Dialogue". Accessed July 19. https://www.mea.gov.in/SpeechesStatements.htm?dtl/29943/Prime+Ministers+Ke ynote+Address+at+Shangri+La+Dialogue+June+01+2018

18. MID. 2018. "Foreign Minister Sergey Lavrov's remarks at a meeting of the Dialogue of Young Diplomats from the Asia-Pacific Region on the sidelines of the Eastern Economic Forum (EEF)". Accessed June 19. http://www.mid.ru/en/foreign policy/news/Lasset publisher/cKNonkJE02Bw/content/id/3342322

19. mofa. 2007. "Confluence of the Two Seas" Speech by H.E. Mr. Shinzo Abe, Prime Minister of Japan at the Parliament of the Republic of India". Accessed June 19. http://www.mofa.go.jp/region/asia-paci/pmv0708/speech-2.html

20. mofa. 2014. "Cabinet Decision on Development of Seamless Security Legislation to Ensure Japan's Survival and Protect its People". Accessed June 19. https://www.mofa.go.jp/fp/nsp/page23e 000273.html

21. Noguchi, Kazuhiko. 2011. "Bringing Realism Back In: Explaining China's Strategic Behavior in the Asia-Pacific". Asia-Pacific Review. 18:2. 60-85.

22. Peter, J. Katzenstein. 1996. The Culture of National Security, Columbia University Press.

23. Phillips, Andrew. 2016. "From Hollywood to Bollywood? Australia's Indo/ Pacific future in a contested Asia". Last modified October 12. Australian Strategic Policy Institute. https://www.aspistrategist.org.au/hollywood-bollywood-australiasindopacific-future-contested-asia/ 
24. pib. 2018. "Shared Vision of India-Indonesia Maritime Cooperation in the IndoPacific". Last modified May 30. Press Information Bureau. http://pib.nic.in/newsite/PrintRelease.aspx?relid $=179630$

25. pib. 2018. "India-Vietnam Joint Statement during the visit of President of Vietnam to India". Accessed October 18. Press Information Bureau. http://pib.nic.in/newsite/PrintRelease.aspx?relid=176933

26. pib. 2018. "Text of Opening remarks by the PM at the Plenary Session of the INDIA- ASEAN Commemorative Summit". Accessed August 19. http://pib.nic.in/newsite/PrintRelease.aspx?relid=175909

27. Scott, David. 2012. "The "Indo-Pacific"- New Regional Formulations and New Maritime Frameworks for US-India Strategic Convergence", Asia-Pacific Review, 19:2, 85-109.

28. Tyler, Melissa Conley, and Shearman, Samantha. Australia's new region: the IndoPacific, Accessed May 18. https://www.eastasiaforum.org/2013/05/21/australiasnew-region-the-indo-pacific/

29. Thang, Nguyen Xuan. 2017. Keynote speech on International Scientific Conference Proceedings 45 Years of Diplomatic Relations and 10 Years of Strategic Partnership. Ho Chi Minh National Academy of Politics. Ha No. 7-11.

30. Thang, Mach Quang. 2018. "Prospects of the Vietnam - India relationship in the context of free and open Indo - Pacific strategy". International Scientific Conference Proceeding VietNam -India Development cooperation in economy, defense, security in the context of free and open Indo - Pacific region. National Political Publishing House. pp.19-31.

31. Whitehouse. 2017. "The United States and India: Prosperity through Partnership". Last modified June 26.The White House. https://www.whitehouse.gov/briefingsstatements/united-states-india-prosperity-partnership/

32. Yi, Wang. 2018. "Minister of Foreign Affairs of China answered foreign and domestic media about Chinese foreign policy and international relation". Accessed December 19. http://www.npc.gov.cn/npc/zhibo/zzzb37/node 9634.htm 